\title{
RECENT RADIOMETRIC DATING OF SOME CAMBRIAN ROCKS IN SOUTHERN AUSTRALIA: RELEVANCE TO THE CAMBRIAN TIME SCALE
}

\author{
James B. JAGO and Peter W. HAINES \\ Department of Applied Geology. School of Engineering. University of South \\ Australia. The Levels, South Australia 5095. Australia. \\ E-mail: jim.jago@unisa.edu.au
}

Jago, J.B. and Haines, P.W. 1998. Recent radiometric dating of some Cambrian rocks in southern Australia: relevance to the Cambrian time scale. [Dataciones racliométricas recientes de algunas rocas cámbricas en Australia meridional: relevancia para la escala temporal cámbrical. Revista Española de Paleontología, n" extr. Homenaje al Prof. Gonzalo Vidal, 115-122. ISSN ()2 13-6937.

\begin{abstract}
The Cambrian time scale is in a state of flux due to a lack of reliable geochronological dates which can be tied to biostratigraphic scales. Most recent Australian dates relevant to the Cambrian geochronologic scale have been determined from the Early Cambrian successions of South Australia and the Middle and Late Cambrian sedimentary and volcanic rocks of western Tasmania. This work has been based on SHRIMP dates using zircon standard SL13. The reliability of these dates is questionable due to doubts as to the reliability of SL13. An analysis of the Lower Cambrian data from South Australia suggests that depending on the standard used the Botoman/Toyonian boundary may be younger than $532.8 \pm 4$ Ma or $522.8 \pm 1.8 \mathrm{Ma}$. The base of the Botoman is older than $526 \pm 4 \mathrm{Ma}$ and may be several million years older, thus suggesting either that the Tommotian and Atdabanian are quite short or that the recently proposed figures of $534 \mathrm{Ma}$ and $528 \mathrm{Ma}$ for the base of the Tommotian and Atdabanian respectively need to be revised to older dates. The Middle Cambrian/Late Cambrian boundary is more likely to have a date of 505 Ma than 498 Ma. The average time span for a trilobite zone (mainly agnostoid based) in the Middle and Late Cambrian is about 535,000 years. This average time span is such that the error bars of most geochronological dates encompass several trilobite zones. Extremely precise and repeatable geochronological dates with good biostratigraphic links will be required to make significant advances in developing an accurate and reliable Cambrian time scale. Currently biostratigraphic work is much more precise and reliable than geochronology.
\end{abstract}

Key words: Cambrian time scale, South Australia, Tasmania, biostratigraphy, geochronology, Middle Cambrian/Late Cambrian boundary.

\section{RESUMEN}

La escala temporal cámbrica se encuentra cambianclo continuamente debido a la falta de dataciones geocronológicas fiables que puedan sobreimponerse con escalas bioestratigráficas. Las dataciones australianas más recientes relevantes para la escala temporal cámbrica han sido determinadas en sucesiones del Cámbrico Temprano de Australia del Sur y en rocas sedimentarias y volcánicas del Cámbrico Medio y Cámbrico Tardío de Tasmania. Este trabajo se ha basado en dataciones SHRIMP que usan el estándar de circón SL13. La exactitud de estas dataciones es cuestionable debido a dudas sobre la fiabilidad del SL13. Un análisis de los datos del Cámbrico Inferior de Australia del Sur sugiere que, dependiendo del estándar usado, el límite Botomense/Toyoniense puede ser más reciente que $532.8 \pm 4 \mathrm{Ma}$ o $522.8 \pm 1.8 \mathrm{Ma}$. La base del Botomense es más antigua que $526 \pm 4$ Ma y puede ser todavía varios millones de años más antigua, lo que sugiere que o bien el Tommotiense y el Atdabaniense son bastante cortos, o bien que las cifras recientemente propuestas de 534 Ma y 528 Ma para las bases de estos respectivos pisos deben ser revisadas hacia dataciones más antiguas. El límite Cámbrico Medio/Cámbrico Tardío es más probable que esté situado en 505 Ma que en 498 Ma. El lapso temporal medio para las zonas de trilobites del Cámbrico Medio y Cámbrico Tardío (principalmente basadas en agnóstidos) es de unos 535.000) años. Dado este lapso temporal medio, resulta que la mayoría de los márgenes de error de las dataciones geocronológicas abarcan varias zonas de trilobites. Para hacer avances significativos en el 
desarrollo de una escala temporal cámbrica precisa y fiable, se requerirán dataciones geocronológicas extremadamente precisas y repetibles, con buenos nexos bioestratigráficos. Hoy día, el trabajo bioestratigráfico es mucho más preciso y fiable que la geocronología.

\section{Palabras clave: Escala temporal cámbrica, Australia del Sur, Tasmania, bioestratigrafía, geocronología, límite Cámbrico Medio/Cámbrico Superior.}

\section{INTRODUCTION}

The Cambrian time scale has been the subject of some discussion in recent years, both in Australia (Shergold, 1995; Young and Laurie, 1996) and elsewhere (e.g., Tucker and McKerrow, 1995; Gradstein and Ogg, 1996). It is in a state of flux (Young and Laurie, 1996) due to a lack of reliable geochronologic dates which can be tied in with the various biostratigraphic scales. The purpose of this paper is to assess critically the value of recent Australian dates used in developing the Cambrian time scale and further to propose modifications, where appropriate, to this part of the time scale.

The two areas of interest are the late Early Cambrian rocks of the Adelaide Fold Belt of South Australia and the late Middle Cambrian Dundas Trough-Mt. Read Volcanics sedimentary-volcanic association of western Tasmania (Figs. 1, 3). The Cambrian geology of these areas, as presently understood, has been described in recent major reviews: the South Australian Cambrian by Gravestock (1995) and the Tasmanian Cambrian in Burrett and Martin (1989). Both areas are important to the understanding of the Neoproterozoic-early Palaeozoic history of the Palaeo-Pacific margin of Gondwana. In particular the dates discussed below for the late Early Cambrian are of considerable significance in trying to understand the timing of events and the sequence of events within the Delamerian Orogeny which affected the Neoproterozoic and Cambrian rocks of the Adelaide Fold Belt. This information will also be relevant to the timing and nature of the Ross Orogeny of the Transantarctic Mountains given the juxtaposition of Australia and Antarctica during the Cambrian.

\section{COMMENT ON SHRIMP DATING}

Most of the radiometric dates quoted herein were obtained using the sensitive high mass-resolution ion microprobe (SHRIMP) at the Research School of Earth Sciences, Australian National University. The SHRIMP has proven a very powerful technique for $\mathrm{U}-\mathrm{Pb}$ dating of zircons through its ability to date single zircon crystals and domains within crystals. However, the SHRIMP technique is totally dependent on the need to compare analytical results with a well-documented, homogeneous standard zircon of known age (for technique details see Compston et al., 1984). The SHRIMP results discussed in this paper have used two different standards; SL13, a 576 Ma gem quality zircon from Sri Lanka, and QGNG, a zircon of Palaeoproterozoic age from the Gawler Craton, South Australia. According to Black et al. (1997) SL13, the dominant standard over the past decade, is now in short supply, and replacement standards are being sought. In dating Tasmanian Cambrian zircons, Black et al. (1997) have utilised both SL13 and QGNG, but report that the particular fragments of SL13 used in their study gave inconsistent results suggesting the existence of a poorly understood compositional heterogeneity in the standard. Thus all final ages given by Black et al. use QGNG. Black et al. (1997) also report that the two standards produce ages which are on average $1.3 \%$ different from each other, with QGNG producing relatively older ages. In order to make meaningful comparisons of available Tasmanian and South Australian SHRIMP data, we thus provide appropriate recalculations, depending on the standard used, as suggested by Black et al. (1997). This is for comparative purposes only. We wish to make it clear that we make no value judgements as to which standard may be giving the more accurate age. However, this problem highlights the

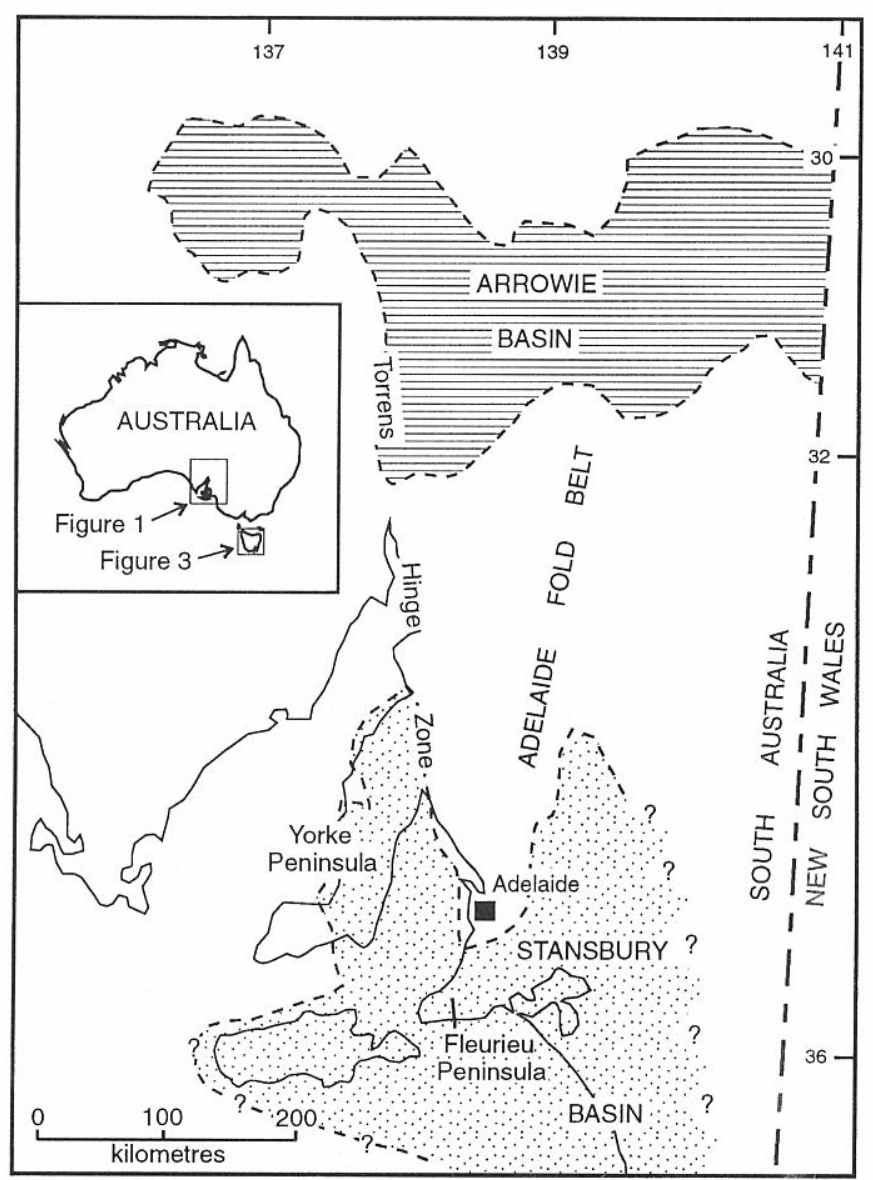

Figure 1. Locality map showing distribution of Cambrian rocks in southern South Australia. 

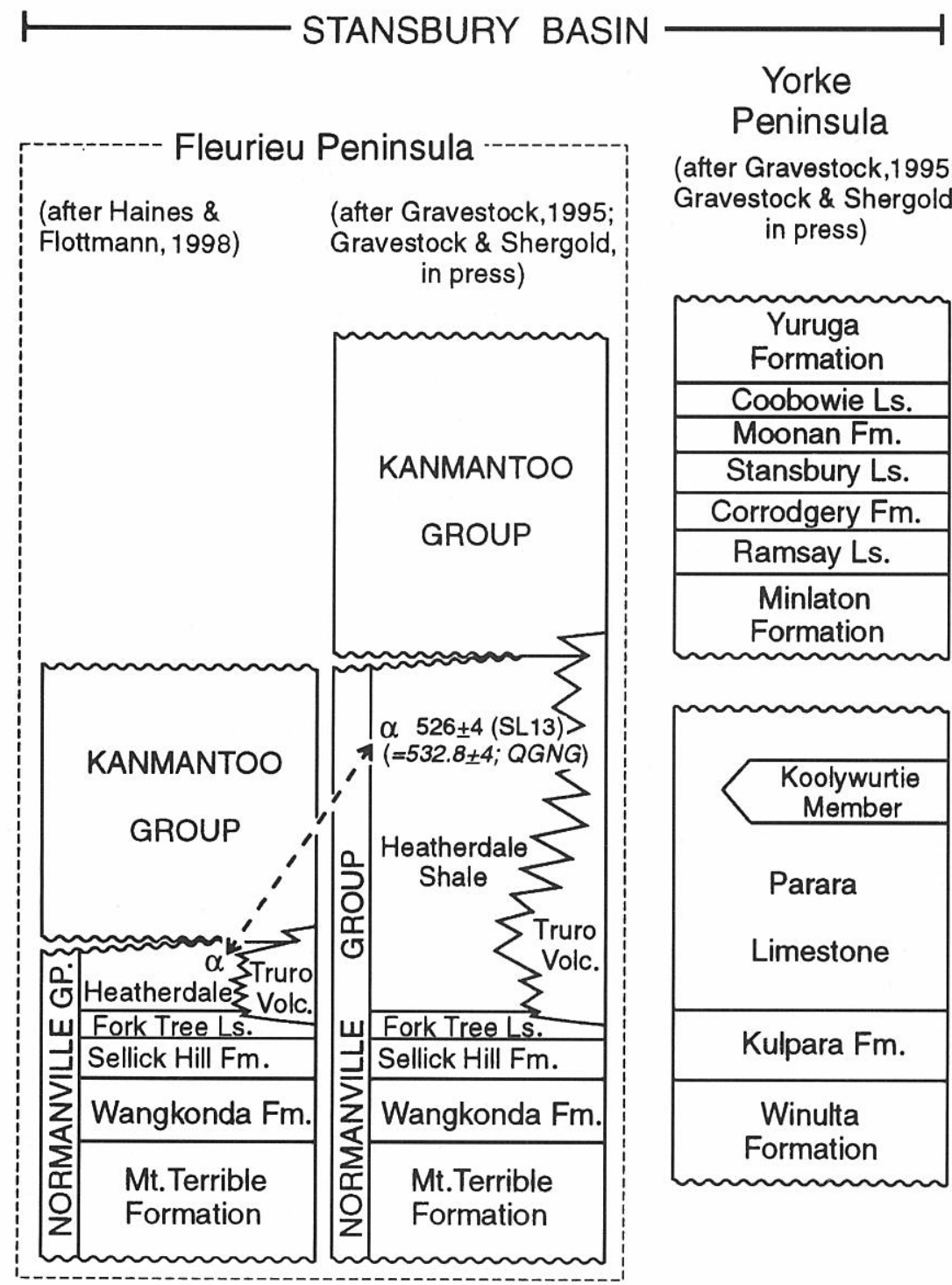

\section{ARROWIE BASIN \\ Flinders Ranges}

(after Gravestock,1995;

Gravestock \& Shergold, in press)

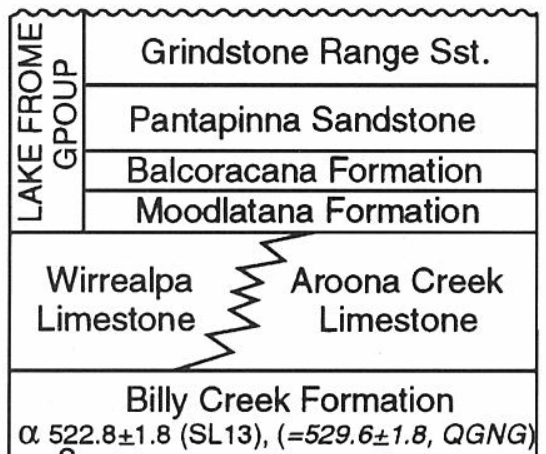

$\alpha 522.8 \pm 1.8$ (SL13), (=529.6 $\pm 1.8, Q G N G)$

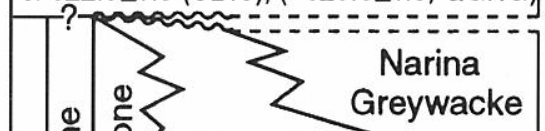

Narina
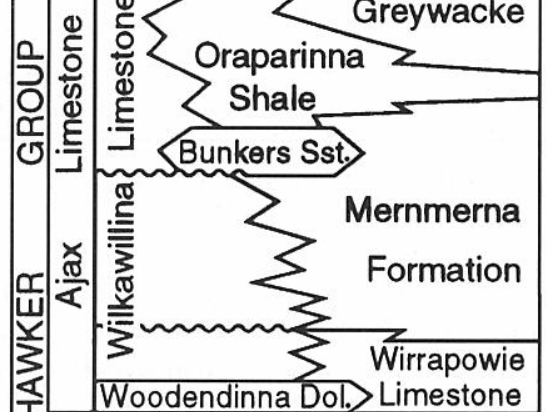

$\sum$ Wirrapowie

Woodendinna Dol.> Limestone

Parachilna Formation

Figure 2. Correlation diagram of the Lower Cambrian successions of Fleurieu Peninsula, Yorke Peninsula and the Flinders Ranges.

potential difficulties of trying to accurately constrain the Australian Cambrian timescale on available radiometric data.

\section{DATES FROM THE EARLY CAMBRIAN SUCCESSION OF THE ADELAIDE FOLD BELT}

The Adelaide Fold Belt preserves a thick accumulation of Neoproterozoic to Middle Cambrian sediments. It is generally accepted that deposition began within an intracontinental rift, continued extension of which led to continental break-up in the late Neoproterozoic (the break up of Rodinia) to create the Palaeo-Pacific margin of Gondwana (e.g., Powell et al., 1994; Veevers et al., 1997). During the Cambrian, thick sediments continued to accumulate and are now preserved in two areas of southern South Australia referred to as the Stansbury and Arrowie Basins, although there was almost certainly some continuity of sedimentation between these areas during deposition. Also beginning in the Cambrian, rocks of the Adelaide Fold Belt east of the Torrens Hinge Zone were deformed by the Early Palaeozoic Delamerian Orogeny (Preiss, 1995). The resulting Delamerian Orogen includes the exposed Adelaide Fold Belt, but extends east beneath cover at least into western Victoria, and may be represented in Tasmania by the Late Cambrian Jukesian Movement. The Delamerian Orogen is generally believed to have once been continuous with the Ross Orogen of the Transantarctic Mountains. Although the Delamerian Orogeny has normally been considered to be Late Cambrian-Ordovician, a recent date of $516 \pm 4 \mathrm{Ma}$ (Preiss, 1995), i.e. late Early Cambrian by the time scale of Young and Laurie (1996), has been obtained from what is generally interpreted as an early syn-tectonic granitoid (e.g., Sandiford et al., 1992).

The critical areas of Cambrian rocks for the purposes of this discussion are the Flinders Ranges (Arrowie 


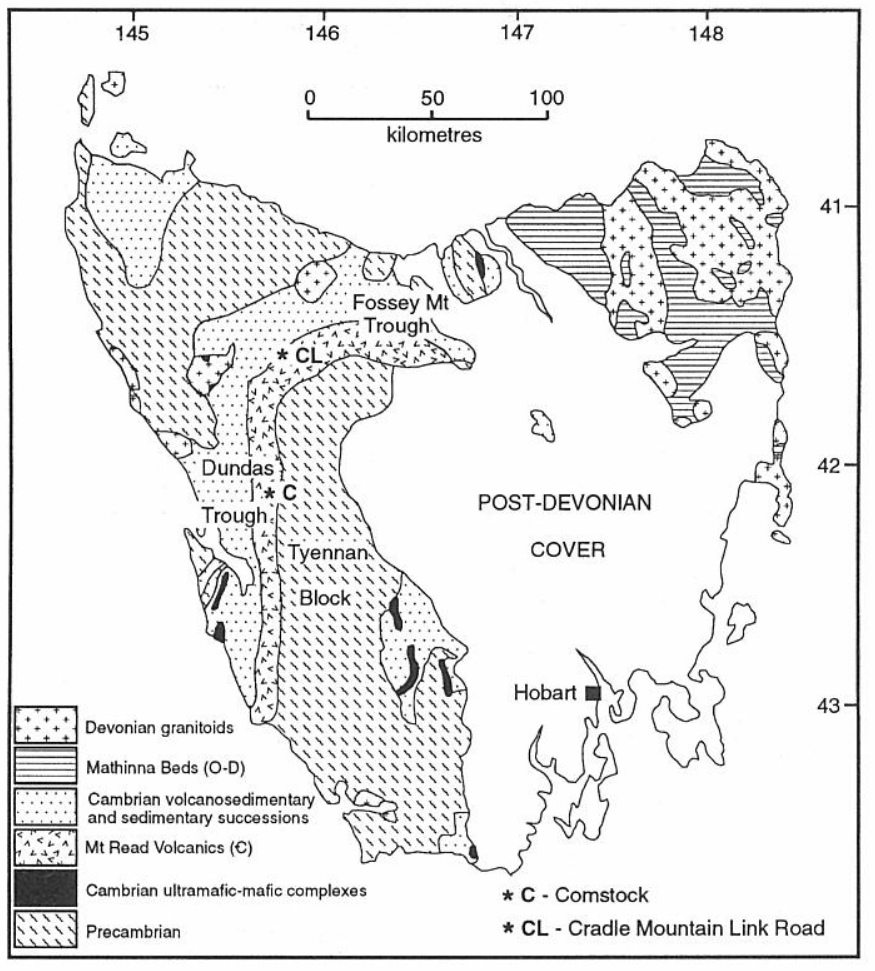

Figure 3. Geological outline of Tasmania.

Basin), Fleurieu Peninsula and Yorke Peninsula (Stansbury Basin). The stratigraphic successions and correlations which have normally been used (e.g., by Gravestock, 1995) are shown in figure 2. A recent alternative view (Fig. 2) has been proposed by Jenkins (1990) and Haines and Flottmann (1998). Of the South Australian successions, the one with the best biostratigraphic control is that in the Flinders Ranges.

Cooper et al. (1992) produced a mean ${ }^{206} \mathrm{~Pb} /{ }^{238} \mathrm{U}$ SHRIMP age of $526 \pm 4$ Ma (95\% confidence level) with standard SL13 (=532.8 \pm 4 Ma with QGNG) on zircons separated from a tuff bed within the upper part of the Heatherdale Shale at Sellicks Hill, Fleurieu Peninsula. However, this age is not very well biostratigraphically constrained in the area of outcrop. The Heatherdale Shale is the top unit of the Normanville Group; it is overlain unconformably by the thick $(\sim 8 \mathrm{~km})$ flyschoid sediments of the Kanmantoo Group which contain only a few very poorly preserved, unidentifiable trilobites and brachiopods (Jago and Haines, 1997).

Cooper et al. (1992) suggest that the Heatherdale Shale is of early to mid Botoman age. The tuff horizon is quite close to the only known trilobite fauna within the Heatherdale Shale, which comprises a few poorly preserved specimens of Atops(?) (Jago et al., 1984; Jenkins and Hasenohr, 1989; Jell et al., 1992). The tuff horizon is over $400 \mathrm{~m}$ stratigraphically higher than the only reasonably well constrained biostratigraphic horizon in the Fleurieu Peninsula Cambrian succession. This horizon contains archaeocyaths in the top of the Sellick Hill Formation and the bottom part of the Fork Tree Limestone. Debrenne and Gravestock (1990) considered these archaeocyaths to be "no older than mid-Atdabanian and arguably Botomian in age", although Zhuravlev and Gravestock (1994) suggest a top Atdabanian age for this fauna.

Gravestock (1995) has used both biostratigraphy and sequence stratigraphy to correlate (Fig. 2) the Cambrian succession on Fleurieu Peninsula with the biostratigraphically better controlled successions of Yorke Peninsula and the Flinders Ranges. Gravestock suggests that the upper part of the Heatherdale Shale should be correlated with the Mernmerna Formation and the Oraparinna Shale in the Central Flinders Ranges, over $400 \mathrm{~km}$ to the north.

Jell (1990) and Jell et al. (1992) have described a well preserved trilobite fauna from the upper part of the Mernmerna Formation. This fauna includes Serrodiscus, Kootenia, Pararaia, Atops, Paleofossus, Redlichia endoi, Hsuaspis bilobata, and others making up what Jell (1990) termed the Pararaia janeae Zone which he suggested is probably equivalent to the upper part of the Botoman in the Siberian scheme and probably with the Tsanglangpu Stage of China.

The upper part of the Heatherdale Shale is correlated with the upper part of the Parara Limestone on Yorke Peninsula, where the Koolywurtie Limestone Member, near the top of the Parara Limestone, contains archaeocyaths of the Syringocnema favus beds which suggest a middle to late Botoman age (Zhuravlev and Gravestock, 1994). Hence the trilobite and archaeocyath data give the same result, i.e. the figure of $526 \pm 4 \mathrm{Ma}$ represents a late Botoman age. This is supported by the work of Zhou and Whitford (1994) who reported a U-Pb SHRIMP age of $525 \pm 8$ Ma with standard SL13 (=531.8 $\pm 8 \mathrm{Ma}$ with QGNG) from a felsic tuff within the Cymbric Vale Formation of western New South Wales. Zhuravlev and Gravestock (1994) suggest that archaeocyaths from the top of the Cymbric Vale Formation have a similar mid to late Botoman age to those of the Koolywurtie Limestone. This agrees with the correlation, based on archaeocyaths, of Kruse (1982) of the Cymbric Vale Formation with the Ajax Mine fauna from the upper part of the Ajax Limestone in the Flinders Ranges. Trilobite faunas from near the top of the Cymbric Vale Formation also suggest a mid to late Botoman age (Jago et al., 1997). However, although the New South Wales information supports that obtained from the Heatherdale Shale the details of the Cymbric Vale radiometric age are yet to be published.

Gravestock and Shergold (in press) report a SHRIMP age of $522.8 \pm 1.8 \mathrm{Ma}$ (SL13) $(=529.6 \pm 1.8 \mathrm{Ma}$ with QGNG) from the lower part of the Billy Creek Formation (Fig. 2) which they consider as late Botoman. However, it should be noted that the Billy Creek Formation contains very few fossils; Bengtson et al. (1990: 15) record only the emuellid trilobite Balcoracania flindersi. The Wirrealpa Limestone, which overlies the Billy Creek Formation contains a small archaeocyathan fauna plus the trilobite Redlichia guizhouensis which suggests correlation with the Redlichia chinensis Zone of the Chinese Lungwangmiao Stage (Bengtson et al., 1990). This is equivalent to the early Toyonian (Debrenne et al., 1990). 
If the ages and correlations discussed above are correct then it would suggest that the Botoman/Toyonian boundary is younger than $526 \pm 4$ (using SL13) or 532.8 \pm 4 (using QGNG) and may be younger than $522.8 \pm 1.8$ (SL13) or $529.6 \pm 1.8$ (QGNG).

If it is accepted that the Heatherdale Shale is of mid to late Botoman age then the above discussion suggests that the Atdabanian/Botoman boundary is probably greater than the $525 \mathrm{Ma}$ suggested by Tucker and McKerrow (1995) or the $\sim 526 \mathrm{Ma}$ suggested by Young and Laurie(1996), although the error bars of the geochronology and the unavailability of exact biostratigraphic data do not rule out the possibility that either of these dates is correct.

It is suggested by Tucker and McKerrow that the base of the Tommotian is $534 \mathrm{Ma}$ and the base of the Atdabanian is $530 \mathrm{Ma}$. However, if the base of the Botoman is older than $526 \mathrm{Ma}$ (and may be several million years older) then it would suggest that either the Tommotian and Atdabanian are quite short or that the figures of 534 and 530 may need to be revised to older dates.

As noted above, on Fleurieu Peninsula the Normanville Group is unconformably overlain by the Kanmantoo Group (Jago et al., 1994). The Kanmantoo Group is intruded by an early syn-tectonic granitoid, known as the Rathjen Gneiss, which has a U-Pb date of $516 \pm 4$ Ma (Preiss, 1995). Chen and Liu (1996) report a $\mathrm{U}-\mathrm{Pb}$ zircon date of $510 \pm 2$ measured at the Royal Ontario Museum from a post-D2 meta-dolerite which intruded Kanmantoo Group rocks.

Due to a lack of diagnostic fossils the biostratigraphic age range of the Kanmantoo Group is unknown. It has generally been argued that the Delamerian Orogeny which folded the Proterozoic-Cambrian sequence of the Adelaide Fold Belt is of Middle to Late Cambrian age with the youngest rocks affected, the biostratigraphically unconstrained Lake Frome Group, being at least in part of Middle Cambrian age (e.g., Gravestock, 1995). This would suggest that the base of the Middle Cambrian would be somewhat older than $510 \mathrm{Ma}$. However, it has been suggested recently by Haines and Flottmann (1998) that the Delamerian Orogeny is a multistage process with "an outer area", the Fleurieu-Nackara Arc being deformed first and the rest of the Adelaide Fold Belt being deformed later in the Cambrian. If this is the case then neither the 516 nor 510 is of value in determining the Cambrian time scale.

\section{LATE MIDDLE CAMBRIAN DATES FROM WESTERN TASMANIA}

Young and Laurie (1996) place the Middle Cambrian/Late Cambrian boundary at about $498 \mathrm{Ma}$, whereas Gradstein and Ogg (1996), following Tucker and McKerrow (1995), suggest a figure of 505 Ma. Young and Laurie also place the Late TempletonianFloran/Undillan, Undillan/Boomerangian and Boomerangian/Mindyallan boundaries respectively at

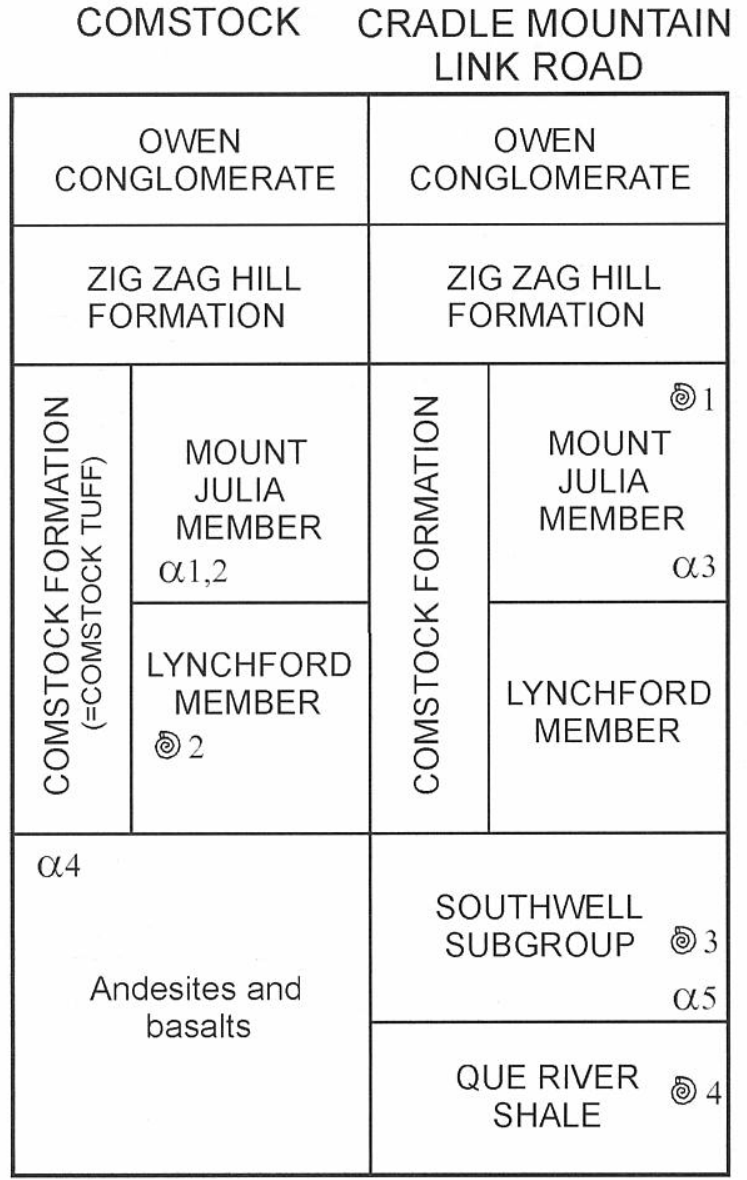

BIOSTRATIGRAPHY (๑))

1. late $L$. laevigata zone fossils

2. late Middle Cambrian fossils

3. G. nathorsti - early L. laevigata zone fossils in clasts

4. E. opimus - P. punctuosus zone fossils

GEOCHRONOLOGY $(\alpha)$

1. $494.4 \pm 3.8(\mathrm{SL} 13,1 \sigma) ;(=500.8 \pm 7.6 ;$ QGNG, $2 \sigma)$

2. $502.5 \pm 3.3 ;(\mathrm{SL} 13,1 \sigma) ;(=509.0 \pm 6.6 ;$ QGNG, $2 \sigma)$

3. $505.3 \pm 3.6$ (QGNG); $(=498.9 \pm 3.6, S L 13)$

4. $502.2 \pm 3.5(\mathrm{SL} 13,1 \sigma) ;(=508.7 \pm 7.0 ;$ Q Q $N G, 2 \sigma)$ $501.5 \pm 5.7(40 \mathrm{Ar} / 39 \mathrm{Ar}, 1 \sigma)$

5. $503.2 \pm 3.8(\mathrm{SL} 13,1 \sigma) ;(=509.7 \pm 7.6 ;$ QGNG, $2 \sigma)$

Figure 4. Summary diagram showing biostratigraphic and geochronologic data of the Mount Read Volcanics from the Comstock and Cradle Mountain Link Road areas of western Tasmania (based on White and McPhie, 1996, and Corbett, 1992). In the Cradle Mountain Link Road area, the Zig Zag Hill and Comstock Formations together correspond to the Mt. Cripps Subgroup of Corbett (1992). All the geochronologic dates in the Comstock area and the lower one in the Cradle Mountain Link Road area are from Perkins and Walshe (1993). These are shown both as originally given by Perkins and Walshe with a $1 \sigma$ error using the SL13 zircon standard and increased by $1.3 \%$ and with a $2 \sigma$ error for comparison with the QGNG zircon standard as used by Black et al. (1997). The upper date in the Cradle Mountain Link Road column is from Black et al. (1997). 


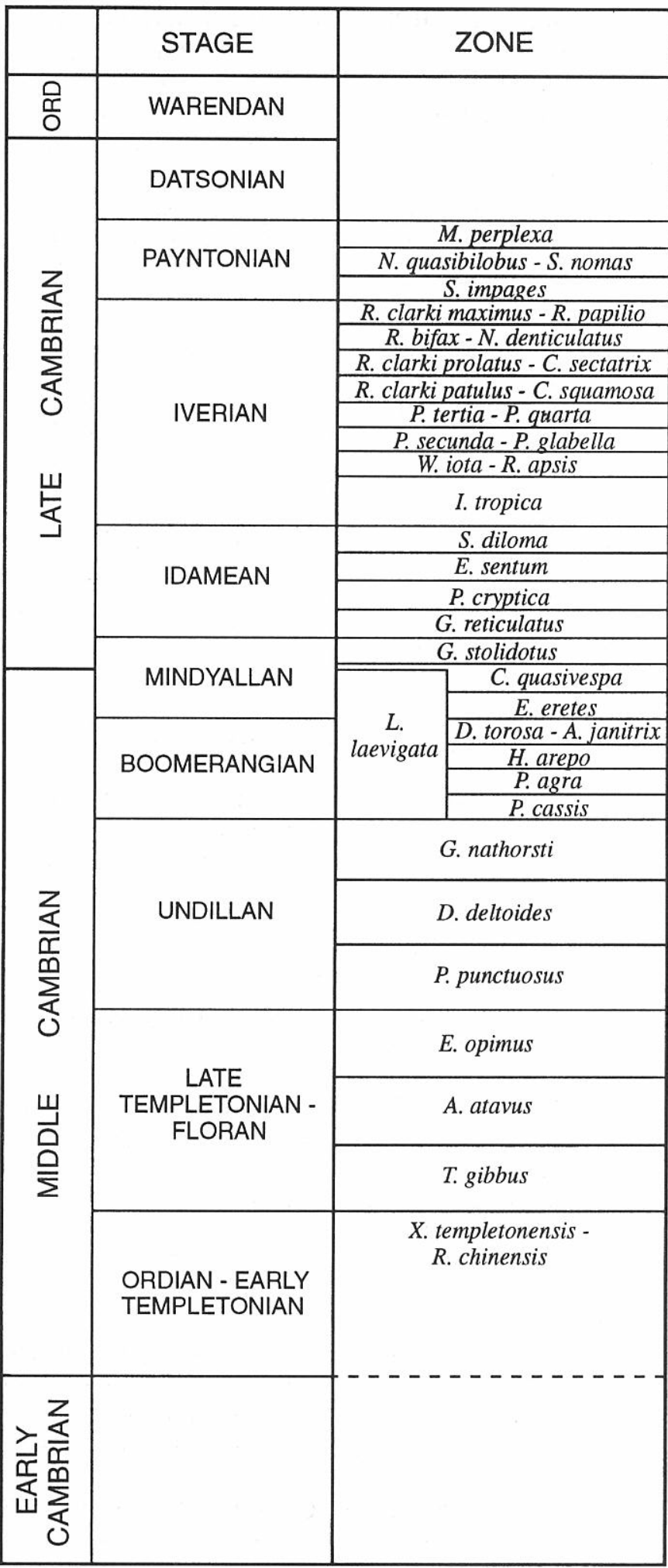

Figure 5. Australian Middle and Late Cambrian biochronological scale. (Based on Shergold, 1995.)

503, 500 and 498.5 Ma. This work is based essentially on the link between the radiometric ages obtained by Perkins and Walshe (1993) and the biostratigraphy outlined by Jago and Brown (1989) for the Middle and Late Cambrian of Tasmania.

Western Tasmania is a structurally complicated, geologically diverse, highly mineralized and thickly vegetated area. The known fossiliferous Cambrian rocks are all of Middle and Late Cambrian age. The majority of Tasmanian Middle and Upper Cambrian sediments were deposited in the narrow Dundas Trough, with intermittent volcanism along the neighbouring Mt. Read Volcanic Arc to the east. Further east again are the Precambrian metamorphics of the Tyennan Block (Fig. 3). Most of the sediments were probably deposited in submarine fan complexes, but there are a few shallow water deposits. There is some intercalation of fossiliferous sediments within the Mt. Read Volcanics.

The stratigraphy of the Mt. Read Volcanics has been described by Corbett (1992) and White and McPhie (1996). The terminology shown in figure 4 is based on these workers; where there is a difference in terminology, that of White and McPhie is used. Geochronologic studies by Perkins and Walshe (1993) and Black et al. (1997) suggest that the Mt. Read Volcanics were formed over a period of about ten million years in the Middle and Late Cambrian. Perkins and Walshe (1993) obtained eight isotopic dates (mainly SHRIMP U-Pb zircon dates using SL13) from the Mt. Read Volcanics. These ages essentially fall into two groups with two ages between 494 and 495 and five ages between 501.0 and 503.2 Ma. Four of these dates are linked with fossiliferous successions.

One of the Perkins and Walshe dates (sample 92-101) is a SHRIMP U-Pb date of $494.4 \pm 3.8 \mathrm{Ma}$ from zircons within volcaniclastic rocks within what they termed the Comstock Tuff, but would now be regarded as occurring low in the Mount Julia Member of the Comstock Formation (Comstock Tuff of Corbett, 1992, and other workers). This sample is stratigraphically above (K. Corbett, pers. comm.) a fossiliferous shallow water limestone of the Lynchford Member (Fig. 4) containing dorypygid and agnostoid trilobites which suggest a late Middle Cambrian age (Jago et al., 1972; Laurie et al., 1995). If the stratigraphic correlation given by White and McPhie (1996) is correct, then the Comstock Formation at Comstock is approximately of early Lejopyge laevigata Zone age as shown by Perkins and Walshe. A second SHRIMP U-Pb date given by Perkins and Walshe (1993) for the Mount Julia Member is $502.5 \pm 3.3$ Ma for volcaniclastics in the Anthony Road area. The fact that both of the above dates are from volcaniclastic rocks means that there is some uncertainty as to the exact age of the zircons.

Perkins and Walshe (1993) give two other dates from just below the Comstock Formation at Comstock. One of these dates, from an andesite, $502.2 \pm 3.5 \mathrm{Ma}$ is a SHRIMP U-Pb zircon date using SL13; the other date, $501.5 \pm 5.7 \mathrm{Ma}$ is an ${ }^{40} \mathrm{Ar} /{ }^{39} \mathrm{Ar}$ date.

The biostratigraphically best constrained date of Perkins and Walshe (1993) is from a rhyolite lava (their sample 91-278) from what they termed (p.1180) "the Upper rhyolite sequence north of the Cradle Mountain link road" as having a SHRIMP zircon age of $503.2 \pm 3.8 \mathrm{Ma}$ (SL13 standard). Although no exact geographic and stratigraphic details are given by Perkins and Walshe, on 
their figure 2 th ey indicate that sample 91-278 came from near the base of the Southwell Subgroup. The Southwell Subgroup is underlain by the Que River Shale which contains a late Floran-early Undillan agnostoid fauna of Euagnostus ofimus Zone to Ptychagnostus punctuosus Zone (Jago, 1977; Laurie et al., 1995). Apparently stratigraphically above sample 91-278, but still within the Southwell Subgroup, is a polymict volcaniclastic conglomerate which contains rare limestone clasts with trilobites which suggest an age of Goniagnostus nathorsti Zone to early Lejopyge aevigata Zone (Jago and McNeill, 1997).

In the Cradle Mountain Link Road area the Southwell Subgroup is overlain by the Comstock Formation (Fig. 4). There are vell preserved trilobites of late Lejopyge laevigata Zone age in the upper part of the Mount Julia Member of the Comstock Formation.

There are tro problems in using the dates of Perkins and Walshe in relating the geochronologic to the biostratigraphic time scale. The first is that they give their results with a $1 \sigma$ error, which encompasses a $67 \%$ confidence limit, whereas the current convention is to give a $2 \sigma$ erro : which encompasses a $95 \%$ confidence limit. Thus a more realistic figure for their sample 91-278 would be $503.2 \pm 7.6 \mathrm{Ma}$. The second problem is the use of zircon stanclard SL13 noted above. The above date when compare 1 with the QGNG zircon standard would be about $509.7 \pm 7.6 \mathrm{Ma}$.

A SHRIMP U-Pb age (standard QGNG) of $505.3 \pm$ $3.6 \mathrm{Ma}$ was obtained by Black et al. (1997) from cogenetic zircous from an ignimbrite which is at the base of the Mount Julia Member on the Cradle Mountain Link Road (K. Corbett, pers comm.). Hence it is stratigraphicall' ' above the fossiliferous limestone clasts of $G$. nathorst Zone to early L. laevigata Zone noted above, but below the late L. laevigata Zone fossils from the upper part of the Mount Julia Member.

The above data would suggest that the Middle Cambrian/Late Cambrian boundary is more likely to have an age of $505 \mathrm{Ma}$ than $498 \mathrm{Ma}$, but a precise figure is not possible at this time. Given the data limitations the difference between $505 \mathrm{Ma}$ and $498 \mathrm{Ma}$ may not seem to be particularly significant, but it is of some significance when it is realised that in the tables given by Young and Laurie (1996) there are 28 trilobite zones (Fig. 5) from the base of the Late Templetonian-Floran (506 Ma according to Young and Laurie) to the top of the Payntonian (491 Ma according to Young and Laurie), i.e. the average time span for a trilobite zone over this interval is about 535,000 years using the Young and Laurie time scale.

Because of the problems discussed above with respect to the dating of the late Middle Cambrian part of the time scale, it could be argued the figures $506 \mathrm{Ma}$ and $491 \mathrm{Ma}$ are of little value. However, whatever the figures should actually be, it is quite clear that the average time span of a Middle or Late Cambrian trilobite zone is such that even the error bars of the geochronological dates encompass over ten trilobite zones.

This suggests that extremely precise geochronological dates with good biostratigraphic links in the Middle and
Late Cambrian will be required to make significant advances in developing an accurate and reliable Cambrian time scale. Such precise links are important in developing an understanding of the sequence of events in geologically complex areas such as western Tasmania. The current situation is that biostratigraphic work is much more precise and reliable than geochronology, although it is essential that work proceeds to provide better links between the biostratigraphic and geochronologic scales.

\section{ACKNOWLEDGEMENTS}

This work was supported by an Australian Research Council(ARC) Small Grant and an ARC Collaborative Grant. Keith Corbett (University of Tasmania) is thanked for valuable advice as to the exact stratigraphic positions of the Tasmanian samples; Chris Bentley is thanked for information on the Cradle Mountain Link Road faunas; David Gravestock is thanked for advice on the South Australian Cambrian successions.

\section{REFERENCES}

Bengtson, S., Conway Morris, S., Cooper, B. J., Jell, P. A. and Runnegar, B. N. 1990. Early Cambrian shelly fossils from South Australia. Association of Australasian Palaeontologists Memoir, 9, 1-364.

Black, L. P., Seymour, D. B., Corbett, K. D., Cox, S. E., Streit, J. E., Bottrill, R. S., Calver, C. R., Everard, J. L., Green, G. R., McClenaghan, M. P., Pemberton, J., Taheri, J. and Turner, N. J. 1997. Dating Tasmania's oldest geological events. Australian Geological Survey Organization, Record, 1997/15, 1-57.

Burrett,C. F. and Martin, E. L. (eds.). 1989. Geology and Mineral Resources of Tasmania. Geological Society of Australia Special Publication, 15, 1-574.

Chen, Y. D. and Liu, S. G. 1996. Precise U-Pb zircon dating of a post-D2 meta-dolerite: constraints for rapid tectonic development of the southern Adelaide Fold Belt during the Cambrian. Journal of the Geological Society, 153, 83-90.

Compston, W., Williams, I. S. and Meyer, C. 1984. U-Pb geochronology of zircons from lunar breccia 73217 using a sensitive high mass-resolution ion microprobe. Journal of Geophysical Research, 89 (supplement), B525-B534.

Cooper, J. A., Jenkins, R. J. F., Compston, W. and Williams, I. S. 1992. Ion-probe zircon dating of a mid-Early Cambrian tuff in South Australia. Journal of the Geological Society, 149, 185-192.

Corbett, K. D. 1992. Stratigraphic-volcanic setting of massive sulfide deposits in the Cambrian Mount Read Volcanics, Tasmania. Economic Geology, 87, 564-586.

Debrenne, F. and Gravestock, D. I. 1990. Archaeocyatha from the Sellick Hill Formation and Fork Tree Limestone on Fleurieu Peninsula, South Australia. Geological Society of Australia Special Publication, 16, 290-309. 
Debrenne, F., Rozanov, A. Yu. and Zhuravlev, A. Yu. 1990. Regular archaeocyaths. Cahiers de Paléontologie, Éditions du CNRS, Paris. 218 pp.

Gradstein, F. M. and Ogg, J. A. 1996. Phanerozoic time scale. Episodes, 19, 3-5.

Gravestock, D. I. 1995. Early and Middle Palaeozoic. South Australia Geological Survey Bulletin, 54 (2), 3-61.

Gravestock, D. I. and Shergold, J. H. In press. Australian Early and Middle Cambrian sequence biostratigraphy with implications for species diversity and correlation. Columbia University Press, New York.

Haines, P. W. and Flottmann, T. 1998. The Delamerian Orogeny and potential foreland sedimentation: a review of age and stratigraphic constraints. Australian Journal of Earth Sciences, 45 (4), 559-570.

Jago, J. B. 1977. A Late Middle Cambrian fauna from the Que River Beds, western Tasmania. Papers and Proceedings of the Royal Society of Tasmania, 111, 41-57

Jago, J. B. and Brown, A. V. 1989. Middle to Upper Cambrian fossiliferous sedimentary rocks. Geological Society of Australia Special Publication, 15, 74-83.

Jago, J. B. and Haines, P. W. 1997. Poorly preserved trilobites and brachiopods from the Kanmantoo Group, Fleurieu Peninsula. Transactions of the Royal Society of South Australia, 121, 75-77.

Jago, J. B. and McNeill, A. W. 1997. A late Middle Cambrian shallow water limestone fauna from the Mt Read Volcanics, northwestern Tasmania. Papers and Proceedings of the Royal Society of Tasmania, 131, 8590.

Jago, J. B., Reid, K. O., Quilty, P. G., Green,G. R. and Daily, B. 1972. Fossiliferous Cambrian limestone from within the Mt. Read Volcanics, Mt Lyell Mine area, Tasmania. Journal of the Geological Society of Australia, 19, 379-382.

Jago, J. B., Daily, B., von der Borch, C. C., Cernovskis, A. and Saunders, N. 1984. First reported trilobites from the Lower Cambrian Normanville Group, Fleurieu Peninsula, South Australia. Transactions of the Royal Society of South Australia, 108, 207-211.

Jago, J. B., Dyson, I. A. and Gatehouse, C. G. 1994. The nature of the sequence boundary between the Normanville and Kanmantoo Groups on Fleurieu Peninsula, South Australia. Australian Journal of Earth Sciences, 41, 445-453.

Jago, J. B., Lin Tian-rui, Davidson, G., Stevens, B. B. J. and Bentley, C. 1997. A late Early Cambrian faunule from the Gnalta Group, Mt. Wright, New South Wales. Transactions of the Royal Society of South Australia, 121, 67-74.

Jell, P. A. 1990. Trilobita. In: Early Cambrian fossils from South Australia. (Auts. Bengtson, S., Conway Morris, S., Cooper, B. J., Jell, P. A. and Runnegar, B. N.). Association of Australasian Palaeontologists Memoir, 9, 257-322.

Jell, P. A., Jago, J. B. and Gehling, J. G. 1992. A new conocoryphid trilobite from the Lower Cambrian of the
Flinders Ranges, South Australia. Alcheringa, 16, 189200.

Jenkins, R. J. F. 1990. The Adelaide Fold Belt: tectonic reappraisal. Geological Society of Australia, Special Publication, 16, 396-420.

Jenkins, R. J. F. and Hasenohr, P. 1989. Trilobites and their trails in a black shale: Early Cambrian of Fleurieu Peninsula, South Australia. Transactions of the Royal Society of South Australia, 113, 195-203.

Kruse, P. D. 1982. Archaeocyathan biostratigraphy of the Gnalta Group at Mt Wright, New South Wales. Palaeontographica, Abteilung A, 177, 1-212.

Laurie, J. R., Jago, J. B. and Bao Jin-song. 1995. Review of Tasmanian Cambrian biostratigraphy. Australian Geological Survey Organization, Record, 1995/69, 1-32.

Perkins, C. and Walshe, J. L. 1993. Geochronology of the Mount Read Volcanics, Tasmania, Australia. Economic Geology, 88, 1176-1197.

Powell, C. McA., Preiss, W. V., Gatehouse, C. G., Krapez, B. and Li, Z. X. 1994. South Australian record of a Rodinian epicontinental basin and its mid-Proterozoic breakup ( 700Ma) to form the Palaeo-Pacific Ocean. Tectonophysics, 237, 113-140.

Preiss, W. V. 1995. Delamerian Orogeny. South Australia Geological Survey Bulletin, 54 (2), 45-60.

Sandiford, M., Foden, J., Zhou, S. and Turner, S. 1992. Granite genesis and the mechanics of convergent orogenic belts with application to the southern Adelaide Fold Belt. Transactions of the Royal Society of Edinburgh: Earth Sciences, 83, 83-93.

Shergold, J. H. 1995. Timescales calibration and development 1: Cambrian. Australian Geological Survey Organisation Record, 1995/30, 1-32.

Tucker, R. D. and McKerrow, W.S. 1995. Early Paleozoic chronology: a review in light of new $\mathrm{U}-\mathrm{Pb}$ zircon ages from Newfoundland and Britain. Canadian Journal of Earth Sciences, 32, 368-379.

Veevers, J. J., Walter, M. R. and Scheibner, E. 1997. Neoproterozoic tectonics of Australia-Antarctica and Laurentia and the $560 \mathrm{Ma}$ birth of the Pacific Ocean reflect the 400 m.y. Pangean Supercycle. Journal of Geology, 105, 225-242.

White, M. J. and McPhie, J. 1996. Stratigraphy and palaeovolcanology of the Cambrian Tyndall Group, Mt Read Volcanics, western Tasmania. Australian Journal of Earth Sciences, 43, 147-159.

Young, G. C. and Laurie, J. R. (eds). 1996. An Australian Phanerozoic Timescale. Oxford University Press, Melbourne. 279 pp.

Zhou, B. and Whitford, D. J. 1994. Geochemistry of the Mt Wright Volcanics from the Wonominta Block, northwestern New South Wales. Australian Journal of Earth Sciences, 41, 331-340.

Zhuravlev, A. Yu. and Gravestock, D. I. 1994. Archaeocyaths from Yorke Peninsula, South Australia and archaeocyathan Early Cambrian zonation. Alcheringa, 18, 1-54. 